\title{
Comparison of RMI 3 and RMI 4 in pre-operative evaluation of ovarian masses
}

\author{
Badugu Rao Bahadur*, Gangadhara Rao Koneru, Prabha Devi Kodey, Jyothi Melam
}

Department of Obstetrics and Gynecology, NRI Medical College and General Hospital, Chinakakani, Mangalagiri, Guntur District, Andhra Pradesh, India

Received: 06 June 2019

Accepted: 08 August 2019

\section{*Correspondence:}

Dr. Badugu Rao Bahadur,

E-mail: drraobahadur@yahoo.com

Copyright: ( $\odot$ the author(s), publisher and licensee Medip Academy. This is an open-access article distributed under the terms of the Creative Commons Attribution Non-Commercial License, which permits unrestricted non-commercial use, distribution, and reproduction in any medium, provided the original work is properly cited.

\begin{abstract}
Background: To differentiate ovarian mass as benign or malignant could change clinical approach. Finding a screening and diagnostic method for ovarian cancer is challenging due to high mortality and insidious symptoms. Risk malignancy index (RMI) has the advantage of rapid and exact triage of patients with ovarian mass.

Methods: Prospective study carried for 2 years at NRI Medical College and General Hospital, Chinakakani, Mangalagiri, Andhra Pradesh, India. 79 patients with ovarian mass were investigated and risk malignancy index (RMI-3 and RMI-4) calculated. Final confirmation was done based on histopathological report. Sensitivity, specificity, positive predictive value and negative predictive value were calculated for RMI 3 and RMI 4 taking histopathology as control and comparison was done.

Results: (n=79); 50 (63.29\%) cases were benign and 29 (36.70\%) were malignant based on histopathology. RMI 4 is more sensitive (68.96\%) than RMI 3 (62.06\%), but RMI 3 is more specific (94\%) than RMI 4 (92\%). The positive predictive value of RMI-3 and RMI- 4 were $85.71 \%$ and $83.33 \%$ respectively. The negative predictive value for RMI4 and RMI- 3 were $83.63 \%$ and $81.03 \%$ respectively.

Conclusions: With increasing age, chance of malignancy increases. RMI 4 was more sensitive than RMI-3, however less specific than RMI 3 in differentiating benign and malignant tumors. The positive predictive value is slightly more for RMI 3, than RMI 4. Negative predictive value is slightly more for RMI 4, than RMI 3.
\end{abstract}

Keywords: CA-125, Ovarian Mass, Risk malignancy index, Ultrasonography

\section{INTRODUCTION}

Women with ovarian cancer have a better prognosis if the full surgical staging procedure is carried out initially by a trained gynecological oncologist. Therefore, preoperative knowledge of the nature of the adnexal mass is necessary so that optimal surgery can be planned at the time of initial treatment. The challenge for general gynecologists has been how to differentiate a benign adnexal mass from a malignant one so that an appropriate referral can be made preoperatively. The risk of malignancy index
(RMI) has been shown to be a triage tool with the potential to reduce the workload in a busy gynecological unit.

Risk malignancy index (RMI) is an equation obtained by multiplying the results of Ultrasonography score (U), the menopause score $(\mathrm{M})$ and the absolute value of serum CA -125. Both RMI 3 and 4 uses the same basic formula but differs in the scores that were assigned to $\mathrm{U}$ and $\mathrm{M}$. RMI 4 includes tumor size(S) measured by ultrasonography. ${ }^{1}$ 
According to data from the United States; each year about 300,000 women are hospitalized because of adnexal masses. $13-21 \%$ of these women have malignant adnexal masses. ${ }^{2,3}$ In women deaths, ovarian cancer is the fifth cancer type. ${ }^{4}$ According to the American Cancer Society data; more than 21,000 new cases were diagnosed in 2014-15 and approximately 14,000 women died because of ovarian cancer. ${ }^{5}$ The 5 -year survival rate is about $30 \%$ in patients diagnosed with advanced stage. Whereas in the cases diagnosed at an early stage, the 5year survival rate is about $90 \% .^{6}$ Thus early diagnosis is important. However, due to nonspecific complaints, the majority of the cases are diagnosed at advanced stages.

In gynecological malignancies; tumor markers have a crucial role in screening, monitoring of treatment, followup and also for predicting recurrence of the disease. ${ }^{7} \mathrm{CA}$ 125 levels increases in only $50 \%$ of early stage ovarian cancer and $90 \%$ of late stage ovarian cancer. Moreover, elevated CA-125 levels may be observed in the variety of the conditions, such as ascites, menstruation, endometriosis, pelvic inflammatory diseases, liver diseases, and other malignant conditions (pancreas, breast, lung, and colon). ${ }^{8}$ Finding a screening and diagnostic method for ovarian cancer is challenging due to high mortality and insidious symptoms. In 1990, Jacobs et al. initially developed RMI 1 that is a simple scoring method based on menopausal status, ultrasound findings and serum CA-125 level. ${ }^{9}$ Tingulstad et al, developed RMI 2 in 1996 and then RMI 3 in 1999. ${ }^{10,11}$ Yamamoto et al, added the parameter of tumor size to RMI scores and developed RMI 4 in $2009 .{ }^{12}$

National Institute of Clinical Excellence and Royal College of obstetrics and gynecology guidelines accepts Risk of Malignancy Index as the best model. ${ }^{13-15}$ Studies showed until now; RMI scoring system has the advantage of rapid and exact triage of the patients. Nevertheless, the literature shows that different populations have different sensitivity and cut-off values $1 .{ }^{16}$

The present study is conducted to compare the ability of RMI 3 and RMI 4 in preoperative differentiation of benign and malignant ovarian masses so that the patient with malignant ovarian mass can be referred to gynecological oncology and to compare the sensitivity, specificity, positive predictive value (PPV) and negative predictive values (NPV) of RMI 3 and RMI 4.

\section{METHODS}

This is a prospective study carried out between August, 2014 to October, 2016 in the Department of Obstetrics and Gynecology, NRI Medical College and General Hospital, Chinakakani, Mangalagiri, Andhra Pradesh, India.

Patients with clinical diagnosis of ovarian mass, who were admitted in the pre-operative ward in the
Department of Obstetrics and Gynecology, were included in the study.

\section{Inclusion criteria}

- All women with clinical diagnosis of having ovarian mass.

\section{Exclusion criteria}

- Proven cases of malignant tumors like biopsy of tumor or cytology of ascetic fluid

- Previous history of genital malignancy

- Past history of chemotherapy or radiotherapy.

A total of 79 patients with clinical diagnosis of ovarian mass were included in the study. They were subjected to detailed history, routine investigations and specific investigations like CA-125 and Ultrasound. RMI 3 and RMI 4 (Table1) was calculated and diagnosed clinically as having either benign or malignant ovarian tumor based on cut-off value. RMI 3 below 200 was considered benign and those with values above 200 were considered malignant. RMI 4 below 450 was considered benign and those with values above 450 were considered malignant. After performing laparotomy and sending the specimen for histopathology, final confirmation was done as either benign or malignant ovarian mass.

\section{Statistical analysis}

Data obtained was subjected to statistical analysis and sensitivity, specificity, positive predictive value and negative predictive value was calculated for RMI 3 and RMI 4 taking histopathology as control and comparison was done.

\section{RESULTS}

Out of 79 cases $50(63.29 \%)$ cases were confirmed as benign ovarian tumor and $29(36.70 \%)$ cases were confirmed as malignant ovarian tumor based on histopathology reports. Majority were benign cases accounting to $63.29 \%$. Malignant cases accounts to $36.70 \%$.

Most of cases were between 31-40 years of age group accounting to $32.91 \%$ (26 cases). Patients between 41-50 years age group were $20(25.31 \%), 51-60$ years age group were $15(18.98 \%), 21-30$ years age group were 9 $(11.39 \%)$, above 60 years age group were $7(8.86 \%)$, below 20 years age group were $2(2.53 \%)$.

Malignant case was seen in $4(20 \%)$ cases in $41-50$ years of age group, $6(23.08 \%)$ cases in $31-40$ years of age group, $3(33.33 \%)$ cases in 21-30 years of age group, 10 (66.67\%) 51-60 years age group. 48 cases $(60.75 \%)$ and $31(39.24 \%)$ were premenopausal and postmenopausal women respectively. Post-menopausal women had higher incidence (19 out of 31 cases) of malignant ovarian 
tumors when compared to pre-menopausal women (10 out of 48 cases). Benign ovarian tumors were more in pre-menopausal women (38 out of 48 cases) and less in post-menopausal women (12 out of 31 cases).

Table 1: Risk of malignancy index (RMI) scoring system. ${ }^{1}$

\begin{tabular}{|lcccc|}
\hline Parameters & RMI 1 & RMI 2 & RMI 3 & RMI 4 \\
\hline Ultrasonography score (U) & 0 & 1 & 1 & 1 \\
\hline No features & 1 & 1 & 1 & 1 \\
\hline 1 feature & 3 & 4 & 3 & 4 \\
\hline$\geq 2$ features & 1 & & 1 & 1 \\
\hline Menopausal status $(\mathbf{M})$ & 1 & 3 & 4 \\
\hline Premenopausal & 1 & 4 & - & - \\
\hline Postmenopausal & 3 & - & & 1 \\
\hline Ca-125 (U/mL) & - & & - & 2 \\
\hline Tumor size (S) & - & - & - & \\
\hline$<7 \mathrm{cms}$ & - & - & & \\
\hline$\geq 7 \mathrm{cms}$ & - & & & \\
\hline
\end{tabular}

Formula for RMI 1,2,3 = U x M x CA-125 value; Formula for RMI $4=\mathrm{U}$ x M x CA-125 x S

43 cases $(54.43 \%)$ had CA- 125 less than 35 , whereas 36 (45.56\%) had CA -125 more than 35.13 cases had 0 Ultrasound (USG) variables, 32 cases had 1 variable and 34 cases had $>1$ variable on USG. Ultrasonography findings showed that as the variables of USG increases (USG Score) chance of malignancy increases. Distribution of cases based on USG score as benign and malignant are shown in Table 2.

Table 2: Distribution of cases based on USG score as benign and malignant.

\begin{tabular}{|lll|}
\hline USG score & Benign (\%) & Malignant $(\%)$ \\
\hline 0 & $13(16.45)$ & 0 \\
\hline 1 & $25(31.64)$ & $7(8.86)$ \\
\hline$>1$ & $12(15.18)$ & $22(27.84)$ \\
\hline
\end{tabular}

Table 3: Distribution of cases as positive and negative according to RMI 3 and RMI 4.

\begin{tabular}{|lllll|}
\hline Method & $\begin{array}{l}\text { True } \\
\text { negative }\end{array}$ & $\begin{array}{l}\text { False } \\
\text { negative }\end{array}$ & $\begin{array}{l}\text { True } \\
\text { positive }\end{array}$ & $\begin{array}{l}\text { False } \\
\text { positive }\end{array}$ \\
\hline RMI 3 & 47 & 11 & 18 & 3 \\
\hline RMI 4 & 46 & 9 & 20 & 4 \\
\hline
\end{tabular}

Table 4: Comparison of RMI-3 and RMI-4.

\begin{tabular}{|lllll|}
\hline Index & Sensitivity & Specificity & PPV & NPV \\
\hline RMI 3 & $62.06 \%$ & $94 \%$ & $85.71 \%$ & $81.03 \%$ \\
\hline RMI 4 & $68.96 \%$ & $92 \%$ & $83.33 \%$ & $83.63 \%$ \\
\hline
\end{tabular}

With RMI-3, 47 cases were identified correctly as benign and 18 cases were identified correctly as malignant. With RMI- 4, 46 cases were identified correctly as benign and 20 cases were identified correctly as malignant (Table 3 ).
3 cases with RMI-3 showed one each of serous cystadenoma, mucinous cystadenoma and dermoid cyst, 4 cases with RMI- 4 showed one each of serous cystadenoma, dermoid cyst and 2 cases with mucinous cystadenoma were false positive.

RMI-3 and RMI-4 showed one each as serous cystadenocarcinoma, immature teratoma, germ cell tumor, adenocarcinoma, borderline tumor, mixed serous and mucinous tumor, 3 cases as granulosa cell carcinoma and one each as mucinous cystadenocarcinoma and metastatic carcinoma by RMI-3 were false negative. Low level of CA -125 and low USG score explains the false negative.

Sensitivity for RMI 3 is $62.06 \%$ and for RMI 4 is $68.96 \%$. Specificity for RMI 3 is $94 \%$ and for RMI 4 is $92 \%$. The positive predictive value for RMI 3 is $85.71 \%$ and for RMI 4 is $83.33 \%$. The negative predictive value for RMI 3 is $81.03 \%$ and for RMI 4 is $83.63 \%$ (Table 4 ).

Mucinous cyst adenoma was the common benign ovarian tumour identified in this study and accounting to about 19 cases $(38 \%)$, followed by serous cystadenoma accounting to 10 cases $(20 \%)$, Simple cysts $7(14 \%)$, Dermoid 7 (14\%), Endometriotic cysts $2(4 \%)$, corpus luteal cysts 1 (2\%) and others $4(8 \%)$. Serous cystadenocarcinoma was the most common variety found in this study with 12 $(41.37 \%)$ cases out of 29 malignant cases followed by mucinous cyst adenocarcinoma accounting to $4(13.79 \%)$. Granulosa cell carcinoma was seen in $3(10.34 \%)$ cases. Metastatic carcinoma was seen in $2(6.89 \%)$ cases, adenocarcinoma was seen in $2(6.89 \%)$ cases. Mixed serous and mucinous carcinoma, immature teratoma, mixed germ cell tumour, clear cell carcinoma, 
dysgerminoma and borderline tumors each were seen in 1 $(3.44 \%)$ case.

Table 5: Comparison of sensitivity indices of RMI in various studies.

\begin{tabular}{|c|c|}
\hline Study & Sensitivity \\
\hline \multirow{2}{*}{ Kumari $\mathrm{N}$ et al, ${ }^{18}$} & $63.63 \%(\mathrm{RMI} 1$ and 3$)$ \\
\hline & $77.27 \%$ (RMI 2 and 4) \\
\hline \multirow[t]{2}{*}{ Kulkarni KA et al, ${ }^{23}$} & $82 \%(\mathrm{RMI} 2)$ \\
\hline & $79 \%$ (RMI 4) \\
\hline \multirow{3}{*}{ Ozbay O et al, ${ }^{26}$} & $60 \%(\mathrm{RMI} 1)$ \\
\hline & $63 \%(\mathrm{RMI} 3)$ \\
\hline & $67 \%$ (RMI 2 and 4) \\
\hline \multirow{3}{*}{ Yamamoto Y et al, ${ }^{19}$} & $73 \%$ (RMI 1 and 3) \\
\hline & $81.1 \%(\mathrm{RMI} 2)$ \\
\hline & $77 \%$ (RMI 4) \\
\hline \multirow{4}{*}{ Insin $\mathrm{P}$ et $\mathrm{al},{ }^{20}$} & $62 \%($ RMI 1) \\
\hline & $71 \%$ (RMI 2) \\
\hline & $64 \%$ (RMI 3) \\
\hline & $69 \%$ (RMI 4) \\
\hline Yavuzcan et al, ${ }^{28}$ & $75 \%$ \\
\hline Sayanesh et al, ${ }^{27}$ & $72 \%$ \\
\hline Ashrafgangooei T et al, ${ }^{16}$ & $89.5 \%$ \\
\hline Hakansson $\mathrm{F}$ et al, ${ }^{29}$ & $92 \%$ \\
\hline Bouzari $\mathrm{Z}$ et al, ${ }^{30}$ & $91 \%$ (RMI 1,2 and 3) \\
\hline \multirow{2}{*}{ Yamamoto Y et al, ${ }^{12}$} & $75 \%$ (RMI 1,2 and 3) \\
\hline & $86.8 \%(\mathrm{RMI} 4)$ \\
\hline Geomini et al, ${ }^{31}$ & $78 \%$ \\
\hline \multirow{2}{*}{ Mooltiya et al, ${ }^{21}$} & $70.6 \%$ (RMI 1) \\
\hline & $80 \%$ (RMI 2) \\
\hline Morgante et al, ${ }^{22}$ & $81 \%$ \\
\hline Tingulstad et al, ${ }^{11}$ & $71 \%$ \\
\hline Tingulstad et al, $1^{0}$ & $71 \%$ \\
\hline Jacobs et al, ${ }^{9}$ & $85.4 \%$ \\
\hline Enakpene et al, ${ }^{24}$ & $88.2 \%$ \\
\hline \multirow{2}{*}{ Present study } & $62.06 \%(\mathrm{RMI} 3)$ \\
\hline & $68.96 \%(\mathrm{RMI} 4)$ \\
\hline
\end{tabular}

\section{DISCUSSION}

Excluding malignancy is typically a two-phase process. An initial evaluation is performed to establish the degree of clinical suspicion that a mass is malignant. If malignancy is suspected, surgical exploration is performed to make a definitive diagnosis.

The likelihood that an ovarian mass is malignant depends mainly upon one or more of the following factors 17, age or menopausal status, physical examination, risk factors, imaging study findings those are consistent with malignancy, laboratory results like CA -125. Survival from ovarian cancer is related to the stage at diagnosis.

The sensitivity index of RMI 3 was $62.06 \%$ and RMI 4 was $68.96 \%$. The sensitivity index of RMI 4 is more than that of RMI 3. It means that RMI 4 is able to correctly identify the malignant ovarian tumors, when compared to RMI 3.

Table 6: Comparison of specificity indices of RMI in various studies.

\begin{tabular}{|c|c|}
\hline Study & Specificity \\
\hline Ertas $\mathrm{S}$ et $\mathrm{al},{ }^{25}$ & $91.5 \%$ \\
\hline \multirow{2}{*}{ Yamamoto Y et al, ${ }^{19}$} & $93.7 \%$ \\
\hline & $92.3 \%$ \\
\hline Yavuzcan et al, ${ }^{28}$ & $91 \%$ \\
\hline Sayanesh et al, ${ }^{27}$ & $94 \%$ \\
\hline Yamamoto Y et al, ${ }^{12}$ & $91 \%$ \\
\hline Tingulstad et al, ${ }^{11}$ & $92 \%$ \\
\hline \multirow{2}{*}{ Present study } & $94 \%$ (RMI 3) \\
\hline & $92 \%$ (RMI 4) \\
\hline
\end{tabular}

Table 7: Comparison of positive predictive value of RMI in various studies.

\begin{tabular}{|ll|}
\hline Study & PPV \\
\hline Ertas S et al, ${ }^{25}$ & $79.1 \%$ \\
\hline Kulkarni KA et al, ${ }^{23}$ & $89 \%$ \\
\hline Yamamoto Y et al, & $82 \%$ \\
\hline Tingulstad et al, $^{10}$ & $79.4 \%$ \\
\hline Present study & $89 \%$ \\
\hline
\end{tabular}

Table 8: Comparison of negative predictive value of RMI in various studies.

\begin{tabular}{|ll|}
\hline Study & NPV \\
\hline Ertas S et al, ${ }^{25}$ & $88.1 \%$ \\
\hline KumarI N et al, ${ }^{18}$ & $84.37 \%$ \\
\hline Ozbay O et al, ${ }^{26}$ & $88 \%$ \\
\hline Insin P et al, ${ }^{20}$ & $89 \%$ \\
\hline Mooltiya et al, ${ }^{21}$ & $80 \%$ \\
\hline Tingulstad et al, ${ }^{10}$ & $80.6 \%$ \\
\hline Present study & $85.1 \%$ \\
\hline
\end{tabular}

The specificity index of RMI 3 was $94 \%$ and RMI 4 was $92 \%$.The specificity index of RMI 3 is more than that of RMI 4. The positive predictive value is slightly more for RMI 3 (85.71\%) than RMI 4 (83.33\%). The negative predictive value is slightly more for RMI 4 (83.63\%), than RMI 3 (81.03\%). In this study it was found that RMI 4 was more sensitive and RMI 3 was more specific.

Percentage of premenopausal women $(60.75 \%)$ in present study is comparable with Kumari $\mathrm{N}$ et al, (56.92\%), Yamamoto $\mathrm{Y}$ et al, (65\%), Insin $\mathrm{P}$ et al, $(56.86 \%)$, Mooltoya et al, (57.9\%), and Morgante et al, (55.64\%) studies. ${ }^{18-22}$ 
Percentage of postmenopausal women (39.24\%) with ovarian masses in present study is comparable with Kulkarni KA et al, (44.1\%), Kumari N et al, (43.07\%), Insin $\mathrm{P}$ et al, (43.13\%), Mooltiya et al, (42.1\%), Morgante et al, $(44.35 \%)$ studies. ${ }^{18,21-23}$

Ovarian malignancy is seen in $20.83 \%$ of premenopausal women in present study which is comparable with Kumari N et al, (24.32\%) and Mooltiya et al, (23.96\%) studies. $^{18,21}$

Ovarian malignancy is seen in $61.29 \%$ of postmenopausal women in present study is comparable with Kulkarni KA et al, (56.2\%), Kumari N et al, (57.14\%), Ashrafgangooei et al, $(57.19 \%)$ studies. ${ }^{16,18,23}$

Sensitivity of CA 125 (68.96\%) in differentiating benign and malignant Ovarian masses preoperatively is comparable with Kumari $\mathrm{N}$ et al, (64\%), Insin $\mathrm{P}$ et al, (75.51\%), Enakpene et al, (72\%) studies. ${ }^{18,20,24}$ Specificity of CA $125(68 \%)$ in present study is comparable with Kumari $\mathrm{N}$ et al, $(72.5 \%)$ study. ${ }^{18} \mathrm{PPV}$ of CA - $125(55.55 \%)$ in present study is comparable with Ertas S et al, (56.7\%), Kumari N et al, (59.25\%), Insin P et al, $(50.68 \%)$ studies. ${ }^{18,20,25}$ NPV of CA $125(79.06 \%)$ in present study is comparable with Kumari $\mathrm{N}$ et al, (76.31\%), Insin P et al, (77.98\%) and Enakpene et al, (78\%) studies. ${ }^{18,20,24}$ Specificity of USG in present study (76\%) is comparable with Insin P et al, (73.24\%) study. ${ }^{20}$

The sensitivity index of RMI 3 and 4 in the present study are $62.06 \%$ and $68.96 \%$ respectively which is comparable to Kumari $\mathrm{N}$ et al, $(63.63 \%)$, Ozbay $\mathrm{O}$ et al, $(60 \%$ and $63 \%)$, Yamamoto $\mathrm{Y}$ et al, (73\%), Insin $\mathrm{P}$ et al, $(62 \%$, $71 \%$ and $64 \%)$, Sayanesh et al, (72\%), Yavuzan et al, (75\%), Hakansson F et al, (92\%), Bouzari Z et al, (91\%RMI 1,2,3), Geomini et al, (78\%), Mooltiya et al, $(70.6 \%)$ and Tingulstad et al, (71\%) (Table 5). ${ }^{10,11,18,21-31}$

The specificity index of RMI 3 and 4 in the present study (94\% and 92\%) respectively is comparable to Ertas S et al, (91.5\%), Yamamoto $\mathrm{Y}$ et al, (93.7\%, and 92.3\%), Yavuzcan et al, (91\%), Sayanesh et al, (94\%), Yamamoto Y et al, (91\%) and Tingulstad et al, (92\%) studies (Table 6)..$^{11,12,19,25-28}$

The positive predictive value of RMI 3 and 4 in the present study $(85.71 \%$ and $83.33 \%)$ is comparable to Ertas $\mathrm{S}$ et al, (79.1\%), Kulkarni KA et al, (82\% and $89 \%$ ), Yamamoto $\mathrm{Y}$ et al, (79.4\%), Tingulstad et al, (89\%) respectively (Table 7). ${ }^{10,19,23,25}$

The NPV of RMI 3 and 4 in the present study $(81.03 \%$ and $83.63 \%)$ is comparable to Kumari $\mathrm{N}$ et al, $(84.37 \%)$, Insin $\mathrm{P}$ et al, (80\%), Mooltiya et al, (80.6\% and $85.1 \%)$ studies (Table 8). ${ }^{18,20,21}$

The limitation of this study is that it is with a small sample size. A significant problem associated with CA125 is that it can be expressed in numerous benign and malignant conditions, which leads to false positive results and it is only expressed by about $50 \%$ of early stage ovarian cancers, which leads to false negative results. ${ }^{32}$

Another tumor marker which has gained attention is the human epididymis secretory protein 4 (HE4). HE4 is expressed in $100 \%$ of endometrioid adenocarcinomas, $93 \%$ of serous adenocarcinomas and $50 \%$ of clear cell ovarian cancers but not expressed in normal surface epithelium. ${ }^{33}$

Moore et al, developed an algorithm, the risk of malignancy algorithm (ROMA), which is based on both CA-125 and HE4. They studied the RMI and ROMA in 457 patients; the results were the ROMA had a sensitivity of $94.3 \%$ while the RMI had a sensitivity of $84.6 \%$ $(\mathrm{p}=0.0029) .^{34}$

Thus, if we use the combined HE 4 with CA -125 we may improve the sensitivity and specificity for distinguishing malignant from benign ovarian tumors but the disadvantages of $\mathrm{HE} 4$ are that it is expensive and difficult to perform in peripheral centers.

Other models of preoperative evaluation should be developed to improve the detection of borderline ovarian tumors.

\section{CONCLUSION}

Increasing age, CA-125>35 U/ml, more number of variables on USG will increase the chance of the tumor being malignant. RMI 4 was more sensitive among the two indices studied, however less specific than RMI 3 in differentiating benign and malignant tumors. The positive predictive value is slightly more for RMI 3, than RMI 4. The negative predictive value is slightly more for RMI 4, than RMI 3. Overall RMI- 4 appears to be the more The RMI is a good diagnostic tool to differentiate between benign and malignant ovarian tumors.

RMI is a simple index which can be used in daily gynecological practice in suspicious and high risk cases so as to identify malignancy in ovarian tumors at an early stage, so that 5 year survival rate can be improved.

Combination of HE 4 with CA -125 may improve the sensitivity and specificity for distinguishing malignancy from benign ovarian tumors but the disadvantages of $\mathrm{HE}$ 4 are that it is expensive and difficult to perform in peripheral centers.

Other models of preoperative evaluation should be developed to improve the detection of borderline ovarian tumors.

\section{ACKNOWLEDGMENTS}

Authors would like to thank the Department of Obstetrics and Gynecology and Oncology of NRI Medical College 
and General Hospital for allowing us to conduct this study. Authors extend their acknowledgement to all women who were included in this study.

Funding: No funding sources

Conflict of interest: None declared

Ethical approval: The study was approved by the Institutional Ethics Committee

\section{REFERENCES}

1. Ong C, Biswas A, Choolani M, Low JJH. Comparision of risk of malignancy indices in evaluating ovarian masses in a Southeast Asian Population. Singapore Med J. 2013:54(3):134-9.

2. Curtin JP. Management of the adnexal mass. Gynecol Oncol. 1994;55:42-6.

3. National Institutes of Health Consensus Development Conference Statement. Ovarian cancer: screening, treatment, and follow-up. Gynecol Oncol. 1994;55:4-14.

4. Davidson SA. Management of the Adnexal Mass. In: Gibbs RS, Karlan BY, Haney AF, Nygaard I, eds. Danforth's Obstetrics and Gynecology. 10 $10^{\text {th }}$ Ed. Philadelphia, PA: Lippincott Williams \& Wilkins, a Wolters Kluwer business; 2008: 1061-1072

5. Siegel R, Ma J, Zou Z. Cancer Statistics. CA Cancer J Clin. 2014;64:9-29.

6. Su Z, Graybill WS, Zhu Y. Detection and monitoring of ovarian cancer. Clin Chim Acta. 2013;415:341-5.

7. Aggarwal P, Kehoe S. Serum tumour markers in gynaecological cancers. Maturitas. 2010;67:46-53.

8. Ozols RF, Rubin SC, Thomas GM. Epithelial ovarian cancer. In: Hoskins WJ, Perez CA, Young R, Barakat $\mathrm{R}$, editors. Principles and practice of gynecologic oncology. 4th ed. Philadelphia, PA: Lippincott Williams and Wilkins; 2005;895-987.

9. Jacobs I, Oram D, Fairbanks J. A risk of malignancy incorporating CA 125 , ultrasound and menopausal status for the accurate preoperative diagnosis of ovarian cancer. Br J Obstet Gynecol. 1990;97:922-9.

10. Tingulstad S, Hagen B, Skjeldestad FE. Evaluation of risk of malignancy index based on serum CA 125, ultrasound findings and menopausal status in the preoperative diagnosis of pelvic masses. Br J Obstet Gynecol. 1996;102:826-31.

11. Tingulstad S, Hagen B, Skjeldestad FE. The risk of malignancy index to evaluate potential ovarian cancers in local hospitals. Br J Obstet Gynecol. 1999;93:448-52.

12. Yamamoto Y, Yamada R, Oguri H. Comparison of four malignancy risk indices in the preoperative evaluation of patients with pelvic masses. Eur J Obstet Gynecol Reprod Biol. 2009;144:163-7.

13. The role of the generalist obstetrician-gynaecologist in the early detection of ovarian cancer. ACOG Committee Opinion No. 280. American college of obstetricians and gynecologists. Obstet Gynecol. 2002;100:1413-6.
14. Royal College of Obstetricians and Gynaecologists. Green-top Guideline No 34: Ovarian Cysts in Postmenopausal Women, October 2003. http://www.rcog.org.uk/en/guidelines-researchservices/guidelines/gtg 34/.

15. NICE Clinical Guidelines. CG122. Ovarian cancer: the recognition and intial management of ovarian cancer. 2011.

16. Ashrafganggooei $T$, Rezaeezadeh M. Risk of malignancy index in preoperative evaluation of pelvic masses. Asian Pac J Cancer Prev. 2011;12:1727-30.

17. Triage of Ovarian Masses, Andreas Obermair, Brisbane. Available at: www.Obermair.info.

18. Kumari N, Gupta V, Kumari R, Makhija A. Int J Reprod Contracept Obstet Gynecol. 2016;5(6):1857-61.

19. Yamamoto Y, Tsuchida A, Ushiwaka T, Nagai R, Matsumoto M, Komatsu J. Comparison of 4 risk-ofmalignancy indexes in the preoperative evaluation of patients with pelvic masses: a prospective study. Clinical Ovarian Other Gynecol Cancer. 2015;7:8-12.

20. Insin P, Prueksaritanond N. Evaluation of four risks of malignancy indices (RMI) in the preoperative diagnosis of ovarian malignancy at rajavithi hospital. Thai J of Obstet Gynaecol. 2013;21(4):163-17.

21. Moolthiya W, Yuenyao P. The risk of malignancy index (RMI) in diagnosis of ovarian malignancy. Asian Pac J Cancer Prev. 2009;10:865-68.

22. Morgante G, la Marca A, Ditto A. Comparison of two malignancy risk indices based on serum CA125, ultrasound score and menopausal status in the diagnosis of ovarian masses. $\mathrm{Br} \mathrm{J}$ Obstet Gynecol. 1999;106:524-7.

23. Kulkarni KA, Premalatha TS, Acharya G. Evaluation of risk of malignancy index 4 (RMI 4) in the preoperative assessment of adnexal masses. J Evid Based Med Healthc. 2016;3(47):2332-6.

24. Enakpene CA, Omigbodun AO, Goecke TW. Preoperative evaluation and triage of women with suspicious adnexal masses using risk of malignancy index. J Obstet Gynaecol. 2009;35:131-8.

25. Ertas S, Vural F, Tufekci EC, Ertas AC, Kose G, Aka N. Predictive value of malignancy risk indices for ovarian masses in premenopausal and postmenopausal women. Asian Pac J Cancer Prev. 2016;17(4):2177-83.

26. Ozbay PO, Ekinci T, Caltekin MD, Yilmaz HT, Temur M, Yilmaz O, et al. Comparative evaluation of the risk of malignancy index scoring systems (14) used in differential diagnosis of adnexal masses. Asian Pac J Cancer Prev. 2015;16(1):345-9.

27. Sayanesh A, Wynants L, Preisler J. Multicentre external validation of IOTA prediction models and RMI by operators with varied training. Br J Cancer. 2013;108:2448-54.

28. Yavuzcan A, Caglar M, Ozgu E. Should cutoff values of the risk of malignancy index be changed for evaluation of adnexal masses in Asian and Pacific populations? Asian Pac J Cancer Prev. 2013;14:5455-9. 
29. Hakansson F, Hogdall EVS, Nedergaard L, Lundvall L, Engelholm SA, Pedersen AT, et al From the danish pelvic mass ovarian cancer study. Risk of malignancy index (RMI) used as a diagnostic tool in a tertiary centre for patients with a pelvic mass. Acta Obstet Gynecol Scand. 2012;91:496-502.

30. Bouzari Z, Yazdani S, Haji Ahmadi M, Barat S, Kelagar ZS, Kutenaie MJ et al. Comparison of three malignancy risk indices and $\mathrm{CA}-125$ in the preoperative evaluation of patients with pelvic masses. BMC Research Notes. 2011;4:206.

31. Geomini P, Kruitwagen R, Bremer GL. The accuracy of risk scores in predicting ovarian malignancy: a systematic review. Obstet Gynecol. 2009;113:384-94.

32. Jacobs I, Bast RC. The CA 125 tumor-associated antigen a review of the literature. Hum Reprod. 1989;4:1-12.

33. Drapkin R, vonHorsten HH, Lin Y, Mok SC, Crum $\mathrm{CP}$, Welch WR, et al. Human epididymis protein 4
(HE4) is a secreted glycoprotein that is over expressed by serous and endometrioid ovarian carcinomas. Cancer Res. 2005;65:2162-9.

34. Moore RG, Jabre-Raughley M, Brown AK, Robison KM, Miller MC, Allard WJ, et al. Comparison of a novel multiple marker assay vs. the risk of malignancy index for the prediction of epithelial ovarian cancer in patients with a pelvic mass. Am J Obstet Gynaecol. 2010;203:228.e1-6.

Cite this article as: Bahadur BR, Koneru GR, Kodey PD, Melam J. Comparison of RMI 3 and RMI 4 in pre-operative evaluation of ovarian masses. Int $\mathrm{J}$ Reprod Contracept Obstet Gynecol 2019;8:3602-8. 